\title{
Some Children's Books by Iowa Writers
}

\section{Y RA CAO}

Although the situation may have been different in past years, the children's book market today is alive and vital; it boasts excellence in both literature and art. Many of its writers and illustrators have achieved success in other or related fields and have found in work for children a deep and lasting satisfaction. This is not to say, of course, that all works published for children have literary value. Standards have been established and awards are now given for excellence in literature and illustration. Each year for more than thirty years a committee of the Children's Services Division of the American Library Association has singled out new books which exemplify high standards of literary and artistic quality. To the outstanding illustrator goes the Randolph Caldecott Award, named for a nineteenth-century English artist who did notable work in illustrating children's books. The outstanding writer for children receives the John Newbery Award, named for a publisher of eighteenth-century England who had a particular interest in issuing books especially intended for young readers.

In the Iowa Authors Collection at The University of Iowa Library are works by more than fifty individuals who have written books for children. To select a few representative authors is a difficult task, but sixteen Iowans have here been chosen to represent different types of writing and literature for pre-teenagers and to illustrate a half-century in the development of literature for children.

One of the foremost authorities in children's literature is May Hill Arbuthnot, a native of Mason City now living in Illinois. She is considered outstanding not for any original stories for youngsters, but because she has edited very fine collections and anthologies for teachers, librarians, parents, counselors, and others who work directly with children. In her long and noteworthy career as an educator, lecturer, and writer at Western Reserve University, she has been the recipient of many awards and honors, including the Constance Lindsay 
Skinner Award of the Women's National Book Association in 1959 and the Regina Medal of the Catholic Library Association in 1964, awarded for distinguished contributions to children's literature. Her books Children and Books and the Arbuthnot Anthology are used as textbooks or major reference works in colleges and universities throughout the country. Children's Books Too Good To Miss, now in its fifth edition, coauthored by Mrs. Arbuthnot, Margaret Mary Clark, and Harriet Geneva Long, is a collection of over 250 titles with annotations and selected illustrations, proven by their popularity with children themselves, for use in selecting good reading material for the library or for developing a child's personal collection.

\section{Legends and Folktales}

Another Iowan, Natalia Belting, is essentially a children's author, though her books are enjoyed by adults also. Born in Oskaloosa, Miss Belting was reared in Iowa and attended Coe College in Cedar Rapids. She received her degrees, however, including the doctorate, from the University of Illinois. Her widely-acclaimed books deal mainly with folklore, especially Indian legends and with the history of North America during the period of French colonization. Her poetry is a type of free verse particularly suitable to the tales which she retells. Some of these tales are interpretations of legends from many countries of the world, and most of them have celestial themes. Calendar Moon, an ALA "Notable" book, is an almanac of stories of the seasons and the names of the months. Its illustrations by Bernarda Bryson have an ethereal, mystical quality in colors of gray and blue. The Sun is a Golden Earring, also illustrated by Miss Bryson, was a runner-up for the Caldecott Award in 1963. This collection of poetic interpretations includes legends of the sun, the rainbow, and the Milky Way. Stories of the constellations are retold in The Stars are Silver Reindeer, in which the illustrations by Esta Nesbitt resemble cave drawings. Miss Belting writes most of her books in prose, however, and three books which illustrate her fine prose are The Moon is a Crystal Ball, Three Apples Fell From Heaven, and The Earth is on a Fish's Back.

Another collector of legends is Harold W. Felton, a lawyer who was born in Neola, Iowa. Mr. Felton now lives in New York, where in his leisure time he writes for young people. Probably his best-known book is his collection of Legends of Paul Bunyan, which contains over 100 stories of the great logging hero. Mr. Felton has also written books about such other legendary heroes of America as John Henry, Mike Fink, and Pecos Bill. All of these stories are told with good taste but 
reflect the strength, wildness, and humor of the then-untamed frontiers of our country. Among many other books that Mr. Felton has to his credit is Cowboy Jamboree, Western Songs \& Lore, a collection of cowboy songs with accompanying legends.

\section{Biography}

One of the most popular types of books for children, yet one of the most difficult to write well, is the biography. Mrs. Arbuthnot states in Children and Books that "For a long time it was difficult to find any biographies for children that were not stereotyped, stuffy, and unpopular." Even today with the plethora of biographical series coming from the publishers' presses, it is often difficult to find a biography that rises above a standardized technique. The biographer must trace the accomplishments, activities, and contributions of a real personality and remain within the framework of factual events. To do this accurately and yet keep the story fresh and interesting to youthful readers necessitates a special kind of creativity and skill.

The Iowa Authors Collection includes some excellent biographical writers. Cornelia Lynde Meigs, though born in Illinois, was associated from early childhood with the Iowa cities of Keokuk and Davenport, first as a student and then as a teacher. Like May Hill Arbuthnot, Miss Meigs is an acknowledged authority on children's literature. Both gained recognition as historians and educators, but Miss Meigs is also noted for the many children's books she published at a time when good literature written primarily for children was less abundant.

For her sensitive portrayal of Louisa May Alcott in Invincible Louisa, she received the John Newbery Award in 1934. This book, wherein the reader becomes intimately acquainted with the biographee, the immediate and remote members of her family and her many acquaintances, all of whom in some way shaped or influenced her destiny, is perhaps somewhat lengthy for the average young reader. Some editions of Invincible Louisa, older ones mainly, include photographs of family members, Louisa at various ages, and the old homestead, plus a six-page chronological table of important dates and events in Miss Alcott's life. Were it not for Miss Meigs's superior literary style and her skill in bringing Louisa May Alcott to life, the book today would probably be considered "stereotyped, stuffy, and unpopular."

Alberta Powell Graham (1875-1955) is one of three Iowa authors who wrote biographies almost exclusively. Her book Thirty-Two Roads to the White House briefly chronicles the lives of the first thirty-two presidents. She also contributed four books to the Abingdon Press "Makers 
of America" series: La Salle, River Explorer; Lafayette, Friend of America; Clara Barton, Red Cross Pioneer; and Christopher Columbus, Discoverer. Although her books draw upon American history, Mrs. Graham's formal training was in the field of music. She moved with her family from Delaware to Ottumwa, Iowa, when she was a small child, was graduated from Ottumwa High School, and studied with private teachers in some of the major schools of music in the country. She was the author of over 300 published songs, and from 1910 to 1921 was supervisor of music in various public schools of Iowa. In 1949, when she was in her seventies, she published Strike Up the Band! a collection of short biographies of thirty-five popular American band musicians from the jazz era to the late 1940's.

Biographies of Thomas Alva Edison, John Paul Jones, Leif Ericson, and Benjamin Franklin have appeared in the "Makers of America" series from the pen of another Iowa author, Ruth Cromer Weir. Mrs. Weir has also authored short biographies of Marco Polo, John Paul Jones, and Christopher Columbus for Row, Peterson's "Real People" series. Mrs. Weir was born in Union, Iowa, attended The University of Iowa in 1924, and has served as nature editor of Childcraft and biography editor of the World Book Encyclopedia. In the Iowa Authors Collection will be found manuscripts of many of Mrs. Weir's books along with extensive correspondence between this author and her publishers.

Meridel Le Sueur, a native of Murray, Iowa, is primarily a short story writer whose works have appeared in many magazines and literary anthologies. In her younger years she acted in motion pictures, wrote for newspapers, taught school, and in 1927 was director of the Children's Theatre of Sacramento, California. She has also written four biographies for young readers: The River Road, a Story of Abraham Lincoln; Chanticleer of Wilderness Road, a Story of Davy Crockett; Nancy Hanks of Wilderness Road, a Story of Abraham Lincoln's Mother; and Little Brother of the Wilderness, the Story of Johnny Appleseed.

\section{Science}

Probably no other area of children's literature has shown such marked improvement as that evident in scientific writing, with scientists now offering young readers a great deal of factual information. Carroll and Mildred Fenton, husband and wife, both of them native Iowans, have contributed in good measure to the high quality of writing found in current scientific literature for children. Dr. Fenton taught for many years in universities in this country and with his wife has 
traveled extensively throughout the western hemisphere. Most of the books by the Fentons are illustrated, many with drawings by Dr. Fenton, others with photographs by Mrs. Fenton. Among their collaborations are The Land We Live On, Worlds in the Sky, and In Prehistoric Seas. Mrs. Fenton has said that when her husband began to write popular books for children and adults, she acted as critic, research assistant, typist, and photographer. They are both trained geologists, and together they have inspired other scientists to direct some of their efforts to children.

Lynn Poole, a native of Eagle Grove, Iowa, has authored some excellent books in the field of science for children. These include such titles as Your Trip Into Space, Diving For Science, and Ballooning in the Space Age. Much of his work is the result of experiments done by Johns Hopkins University research teams, some of this material having been the basis for the televised "Johns Hopkins Science Review," of which Mr. Poole was creator and host. Both the Fentons and Lynn Poole have covered a wide range of scientific subjects, including geology, biology, astronomy, and medicine, for the middle and upper elementary grade and junior high school students.

\section{Fairy Tales}

Cornelia Meigs's first published book was a fairy story centering around "The Beggar," a flute-playing Robin Hood sort of individual with magic in his touch. The book is called Kingdom of the Winding Road and was published in 1915. May Hill Arbuthnot collected over 150 fairy stories, old and new, including folktales from various countries, fables, and myths. These were published under the title Time for Fairy Tales. Elves and Ellefolk, Tales of the Little People, by Natalia Belting, contains stories of Leprechauns, elves, korrigans, and goblins. A relative newcomer to the field of children's literature is Mary Calhoun. Miss Calhoun is a native of Keokuk, a graduate in journalism from The University of Iowa, an ex-newspaper reporter, and now a housewife and mother living in Colorado. Among her recent books are the following fairy tales: The Runaway Brownie, The Hungry Leprechaun, The Thieving Dwarfs, and The Witch of Hissing Hill.

\section{Animals}

Stories in which an animal is the protagonist or is a leading character are popular with children. This is evident in the long life of some television shows which feature dogs, dolphins, and bears in starring roles. Natalia Belting's Indy and Mr. Lincoln is the story of a "most remark- 
able pig," supposedly based on a true incident in the life of Abraham Lincoln. In Verity Mullens and the Indian by Miss Belting, Verity, the dog owned by Priscilla Mullens, sets out to discover a turkey but finds an Indian instead. In 1947 Ruth Weir published a little story about a dog, Rags, An Orphan of the Storm, and Mary Calhoun wrote about a coon dog called Houn' Dog, humorously illustrated by Caldecott-Award-winning artist Roger Duvoisin.

Phil Stong (1899-1957), best known, no doubt, for his book State Fair, wrote some sixteen books for young readers, most of them illustrated by Kurt Wiese, noted artist for children's books. Among these are two books about dogs, No-Stitch: the Hound and Positive Petel Mr. Stong was born in Van Buren County, Iowa. His work is humorous and sensitive, and so universally appealing that some of it has been translated into other languages. His great imagination gave us characters like Honk: the Moose; Captain Kidd's Cow; Censored, the Goat; Mexico, a mule in High Water; and Prince and Tam O'Shanter, a horse and pig in The Prince and the Porker.

A new luminary on the Iowa literary scene is Eleanor Pownall Simmons, who until three books ago was known primarily as an artist. She has illustrated the works of several other children's authors and her drawings have also appeared in women's magazines. To Iowa City's very young generation, Ellie Simmons is best known for the exciting and imaginative mural that decorates the Story Hour room in the Iowa City Public Library. In recent years she has become an author under the aegis of David McKay Company, publishers. Born in Des Moines, she was graduated from The University of Iowa, and she is currently living in Iowa City, where her husband is on the staff of the University. One of her latest books is a true picture book, having no words save the title, Dog. The pictures by Mrs. Simmons recount the story of a little boy who acquires and cares for a curly-haired white pup.

Other animals prominently featured in stories by Iowans include $A$ Horse Named Justin Morgan, Harold Felton's factual and sensitive story of a boy whose great fondness for a plucky little work horse effects the perpetuation of a respected breed of American work horses. Cats are featured by Natalia Belting in her book about legendary cats called Cat Tales and by Mary Calhoun in her book, Wobble, the Witch Cat.

\section{Other Children}

Children of all ages are interested in stories about other children, particularly of their own age. They want to know if their problems are similar and how such problems are faced and solved by others. They 
are interested in knowing how other children live, play, and work. Ellie Simmons wrote two books about a little girl named Mary whose sensitivity and femininity create the action in Mary, the Mouse Champion and Mary Changes Her Clothes. As in Dog, the illustrations are appropriate to the subject, and in the latter book a touch of femininity is suggested by the pink pages, cover, and jacket of the book. Mary Calhoun's heroine stars in three books about a 10-year-old girl in the awkward phase of growing up and having to adjust to changes around her and within her. Katie John, Depend on Katie John, and Honestly, Katie John! are books written for the pre-teenage girl. In another book, Miss Calhoun recounts the meeting of Sarah and the Cat Woman and their subsequent adventures in The House of Thirty Cats.

Crowell-Collier has published a series of children's books by famous authors of adult literature under the title "Modern Masters Books for Children." One of these, written by Paul Engle of Iowa City and illustrated by Ray Prohaska, is called Who's Afraid? It is about a small boy alone on his grandfather's farm who dares to face the animals and to walk through the tall corn all by himself. In Cowboy Cal and the Outlaw, Mary Calhoun writes about a determined boy and an equally determined wild horse, and in River-Minded Boy, she relates a lad's experiences on the "Black Hawk," a Mississippi towboat. Duane Bradley, a native of Clarinda, Iowa, has recently written Meeting With a Stranger, a book in which a boy confronts a present-day social problem. Teffera is a young Ethiopian shepherd boy who sees the ancient and traditional ways of his African village changed by a smiling stranger from America. Mrs. Bradley's book is illustrated with excellent black and white drawings by E. Harper Johnson. Ruth Cromer Weir's The Great Big Noise is a mystery story in which two preschool boys, visited by their adventuring grandfather, seek the source of a loud, growling sound which startles them in the night. Three offerings of this kind in the Iowa Authors Collection that can be recommended are Mystery at the Red House by Cornelia Meigs, Mystery at the Shoals by Duane Bradley, and a rollicking misadventure by Phil Stong called Way Down Cellar.

\section{Christmas}

Christmas time is the setting for several books by Iowa authors. Grace Noll Crowell, a native of Inland, Iowa, wrote five books about boys and girls at this special time of the year. One of these, Rebecca, The Little Serving Maid, takes place in Bethlehem at the first Christmas. Three of her other books feature a presumably early-nineteenthcentury lass who is introduced to us in Happiness for Sale as "Little 
Prudence Parker of long ago. ..." In this and the two other books of less than fifty pages each, The Shining Hour and The Glory of Giving, Prudence illustrates certain Christian virtues which triumph over wrongdoing and evil thoughts. In Mrs. Crowell's Little Boy Down the Lane, Noel Hanson learns the meaning of Christmas as he performs his simple, everyday tasks for his widowed mother and their neighbors. Prudence, Noel, and Rebecca are faintly reminiscent of the children portrayed in the eighteenth- and nineteenth-century morality stories. They are good children, unyielding to besetting temptation, but have a somewhat unreal quality.

Paul Engle has written a Christmas book which is excellent fare for adults and children. An Old Fashioned Christmas is a collection of stories which had earlier appeared as a short book entitled Prairie Christmas, here supplemented with related poems. Making this volume a special item in the Iowa Authors Collection are its illustrations by Ellie Simmons, whose technique is in perfect harmony with the text. It is a warm and beautiful book which contains much traditional Christmas Americana. An older Christmas story by Cornelia Meigs, Mother Makes Christmas, was published in 1940. Lois Lenski, illustrator and author, drew the pictures for the book. It, too, is a good look at the Christmas-time of another era.

\section{Historical Fiction}

The Dutch Colt and Fair Wind to Virginia, by Cornelia Meigs, both have their setting in Revolutionary America. The Dutch Colt, a story of two Quaker children in the early days of Pennsylvania, has this year been reprinted by Macmillan. Miss Meigs's The Willow Whistle is a story of Indians and pioneers which was first published in 1931 and is still popular enough to keep in print.

Harold Felton's William Phips and the Treasure Ship is based on historical events and concerns the search for a fortune aboard a sunken Spanish galleon by a young sea captain, Mr. Phips, who later became a governor of the Massachusetts Bay Colony. Two books by Natalia Belting that relate to the early history of the United States are Pierre of Kaskaskia, Pioneer Boy of New France and In Enemy Hands, a Story of the French and Indian War.

Madeline Darrough Horn, an Iowa City author, is a writer of pioneer stories. Although born in Illinois, she has lived in Iowa for many years, much of the time in Iowa City, where her husband taught at the University until his recent death. Most of Mrs. Horn's books are set in the Midwest, and she writes with great understanding and real- 
ism. Farm on the Hill has a special made-in-Iowa quality because the illustrations are by Grant Wood, a personal friend of the Horns who expressed the wish to do the pictures for this book. Log Cabin Family is a humorous and charming story of the Midwest, good for reading aloud. Its drawings by Francis McCray are faintly reminiscent of Grant Wood, but they have a softness not characteristic of Wood's technique.

By no means all the books by these sixteen authors have been mentioned above, but those of their books that are suitable for children are included in the following list. Some of these books are out of print at the present time, but hopefully publishers will continue to reprint older works of good literary quality.

\section{Arbuthnot, May Hill}

Arbuthnot Anthology of Children's Literature; single volume edition of Time for poetry, Time for fairy tales, and Time for true tales. A collection of poems and stories for children, to be used in the classroom, home, or camp; especially planned for college classes in children's literature. Illustrated by Arthur Paul (and others). Rev. ed. Chicago: Scott, Foresman, 1961.

Children and Books. Revised edition. Chicago: Scott, Foresman and Company, 1957.

Children's Books Too Good to Miss, by May Hill Arbuthnot, Margaret Mary Clark, and Harriet Geneva Long. Cleveland: The Press of Western Reserve University, 1966.

Time For Fairy Tales, old and new. Compiled by May Hill Arbuthnot. Illustrated by John Averill, Wade Ray, Seymour Rosofsky, and Debi Sussman; designed by Hal Kearney. Chicago: Scott, Foresman and Company, 1952. Ages 4-14.

Time For Poetry. Compiled by May Hill Arbuthnot and Shelton L. Root, Jr. Illustrated by Arthur Paul. Third general edition. Chicago: Scott, Foresman and Company, 1952, 1961, 1968. All ages.

Time For True Tales, and almost true. Compiled by May Hill Arbuthnot. Illustrated by Rainey Bennett; designed by Hal Kearney. Chicago: Scott, Foresman and Company, 1953. Ages 4-14.

\section{Belting. Natalia}

Calendar Moon. Illustrated by Bernarda Bryson. New York: Holt, Rinehart and Winston, 1964. Ages 6 up.

Cat Tales. Illustrated by Leo Summers. New York: Henry Holt and Company, 1959. Ages 7-12.

The Earth is on a Fish's Back; Tales of Beginnings. Illustrated by Esta Nesbitt. New York: Holt, Rinehart and Winston, 1965. Ages 9-12.

Elves and Ellefolk; Tales of the Little People. Illustrated by Gordon Laite. New York: Holt, Rinehart and Winston, 1961. Ages 9-12.

In Enemy Hands, a Story of the French and Indian War. Illustrated by Harry Lees. Indianapolis: The Bobbs-Merrill Company, Inc., 1953. Ages 9-15. 
Indy and $M r$. Lincoln. Illustrated by Leonard Everett Fisher. New York: Holt, Rinehart and Winston, 1960. Ages 5-9.

The Long-tailed Bear and Other Indian Legends. Illustrated by Louis F. Cary. Indianapolis: The Bobbs-Merrill Company, Inc., A subsidiary of Howard W. Sams \& Co., Inc., Publishers, 1961. Ages 7-12.

The Moon is a Crystal Ball; Unfamiliar Legends of the Stars. Illustrated by Anne Marie Jauss. Indianapolis: The Bobbs-Merrill Company, Inc., 1952. Ages 7-12.

Pierre of Kaskaskia, Pioneer Boy of New France. Illustrated by Paul Busch. Indianapolis: The Bobbs-Merrill Company, Inc., 1951. Ages 9-12.

The Stars are Silver Reindeer. Illustrated by Esta Nesbitt. New York: Holt, Rinehart and Winston, 1966. Ages 9-12.

The Sun is a Golden Earring. Illustrated by Bernarda Bryson. New York: Holt, Rinehart and Winston, 1962. Ages 6 up.

Three Apples Fell from Heaven; Unfamiliar Legends of the Trees. Drawings by Anne Marie Jauss. Indianapolis: The Bobbs-Merrill Company, Inc., 1953. Ages 9-12.

Verity Mullens and the Indians. Illustrated by Leonard Everett Fisher. New York: Holt, Rinehart and Winston, 1960. Ages 5-9.

\section{Bradley, Duane}

Cappy and the Jet Engine. Pictures by Alice Cosgrove. Philadelphia: J. B. Lippincott Company, 1957. Ages 7-10.

Electing a President. Decorations by Henry R. Martin. Princeton, N.J.: D. Van Nostrand Company, Inc., 1963. Ages 10-16.

Engineers Did It! Illustrated by Anne Marie Jauss. Philadelphia: J. B. Lippincott Company, 1958. Ages 8-12.

Meeting With a Stranger. Illustrated by E. Harper Johnson. Philadelphia: J. B. Lippincott Company, 1964. Ages 8-12.

Mystery at the Shoals. Illustrated by Velma Ilsley. Philadelphia: J. B. Lippincott Company, 1962. Ages 9-13.

The Newspaper-Its Place in a Democracy. Princeton, N.J.: D. Van Nostrand Company, Inc., 1965. Ages 11 up.

Sew It and Wear It. Illustrated by Ava Morgan. New York: Thomas Y. Crowell Company, 1966. Ages 10 up.

Time for You: How Man Measures Time. Illustrated by Anne Marie Jauss. Philadelphia: J. B. Lippincott Company, 1960. Ages 9-13.

\section{Calhoun, Mary}

Cowboy Cal and the Outlaw. Illustrated by Frank Nicholas. (New York): William Morrow and Company, 1961. Ages 6-10.

Depend on Katie John. Pictures by Paul Frame. New York: Harper \& Row, Publishers, 1961. Ages 8-12.

High Wind For Kansas. Illustrated by W. T. Mars. New York: William Morrow \& Company, 1965. Ages 6-10.

Honestly, Katie John! Pictures by Paul Frame. New York: Harper \& Row, Publishers, 1963. Ages 8-12.

Houn' Dog. Illustrated by Roger Duvoisin. New York: William Morrow \& Company, 1959. Ages 5-10. 
The House of Thirty Cats. Pictures by Mary Chalmers. New York: Harper \& Row, Publishers, 1965. Ages 8-12.

The Hungry Leprechaun. Illustrated by Roger Duvoisin. New York: William Morrow and Company, 1962. Ages 4-8.

Katie John. Pictures by Paul Frame. New York: Harper \& Row, Publishers, 1960. Ages 8-12.

Making the Mississippi Shout. Illustrated by Paul Galdone. New York: William Morrow and Company, 1957. Ages 8-12.

The Nine Lives of Homer C. Cat. Pictures by Roger Duvoisin. New York: William Morrow \& Company, 1961. Ages 4-8.

River-Minded Boy. Illustrated by William R. Lohse. New York: William Morrow \& Company, 1958. Ages 10-14.

The Runaway Brownie. Pictures by Janet McCaffrey. New York: William Morrow \& Company, 1967. Ages 4-8.

Sweet Patootie Doll. Illustrated by Roger Duvoisin. New York: William Morrow \& Company, 1957. Ages 4-8.

The Thieving Dwarfs. Pictures by Janet McCaffrey. New York: William Morrow \& Company, 1967. Ages 4-8.

The Witch of Hissing Hill. Pictures by Janet McCaffrey. New York: William Morrow \& Company, 1964. Ages 4-8.

Wobble, the Witch Cat. Pictures by Roger Duvoisin. New York: William Morrow \& Company, 1958. Ages 4-8.

\section{Crowell, Grace Noll}

A Child Kneels to Pray. Illustrations by Lee Mero. Minneapolis: Augsburg Publishing House, 1950. Ages 5-12.

The Glory of Giving. Illustrated by Lee Mero. Minneapolis: Augsburg Publishing House, 1945. Ages 8-12.

Happiness for Sale. Illustrated by Lee Mero. Minneapolis: Augsburg Publishing House, 1943. Ages 8-12.

Little Boy Down the Lane. Illustrated by Lee Mero. Minneapolis: Augsburg Publishing House, 1952. Ages 8-12.

The Little Serving Maid. Illustrated by Lee Mero. Minneapolis: Augsburg Publishing House, 1953. Ages 8-12.

My Book of Praise. Illustrated by Lee Mero. Minneapolis: Augsburg Publishing House, 1955. Ages 5-12.

The Shining Hour. Illustrated by Lee Mero. Minneapolis: Augsburg Publishing House, 1944. Ages 8-12.

\section{Engle, Paul}

Golden Child. Illustrated by Leonard Everett Fisher, New York: E. P. Dutton \& Co., Inc., 1962. All ages.

An Old Fashioned Christmas. Illustrated by Eleanor Pownall Simmons. New York: The Dial Press, 1964. All ages.

Who's Afraid? Illustrated by Ray Prohaska. New York: The Crowell-Collier Press, 1963. Ages 4-8.

$$
\text { Felton, Harold W. }
$$

Bowleg Bill, Seagoing Cowpuncher. Illustrated by William Moyers. Englewood Cliffs, N.J.: Prentice-Hall, Inc., 1957. Ages 10-14. 
Cowboy Jamboree: Western Songs \& Lore. Collected and told by Harold W. Felton. Musical Arrangements by Edward S. Breck. Illustrations by Aldren A. Watson. Foreword by Carl Carmer. New York: Alfred A. Knopf, 1951. All ages.

Edward Rose, Negro Trail Blazer. Illustrated with photographs, prints of the period, and maps. New York: Dodd, Mead \& Company, 1967. Ages 10-16.

Fire-Fightin' Mose; Being: An Account of the Life and Times of the World's Greatest Fire Fighter, Member of the New York City Volunteer Fire Department, and of the Company of Lady Washington, Engine No. 40 , a machine of greatest excellence, known as the White Ghost. Illustrated by Aldren A. Watson. Foreword by B. A. Botkin. New York: Alfred A. Knopf, 1955. Ages 10-16.

A Horse Named Justin Morgan. Illustrated by Leonard Everett Fisher. New York: Dodd, Mead \& Company, 1962. Ages 10-16.

Jim Beckwourth, Negro Mountain Man. Illustrated with photographs, prints of the period, and maps. New York: Dodd, Mead \& Company, 1966. Ages 10-16.

John Henry and His Hammer. Illustrations by Aldren A. Watson. New York: Alfred A. Knopf, 1950. Ages 10-16.

Legends of Paul Bunyan. Compiled and edited by Harold W. Felton. Illustrated by Richard Bennett. New York: Alfred A. Knopf, 1961. Ages 10 up.

Mike Fink, Best of the Keelboatmen, Being a Revealing and Trustworthy Account of events in the Life of the Renowned Riverman, Indian Scout, and Relentless Enemy of divers and sundry outlaws. Containing Facts, Anecdotes, History, Legend, and Folklore of the Unique and Justly Famed Hero including his experiences in his Inimitable Craft, the Lightfoot. Taken from ancient original sources by Harold W. Felton. Tastefully amplified and illustrated by Aldren A. Watson. New York: Dodd, Mead \& Company, 1960. Ages 10-16.

New Tall Tales of Pecos Bill. Illustrated by William Moyers. Englewood Cliffs, N.J.: Prentice-Hall, Inc., 1958. Ages 10-14.

Pecos Bill and the Mustang. Pictures by Leonard Shortall. Englewood Cliffs, N.J.: Prentice-Hall, Inc., 1965. Ages 4-8.

Pecos Bill, Texas Cowpuncher. Illustrations by Aldren Auld Watson. New York: Alfred A. Knopf, 1949. Ages 10-16.

Sergeant O'Keefe and His Mule, Balaam. Illustrated by Leonard Everett Fisher. New York: Dodd, Mead \& Company, 1962. Ages 10 up.

William Phips and the Treasure Ship. Drawings by Alvin Smith. New York: Dodd, Mead \& Company, 1965. Ages 10-14.

The World's Most Truthful Man; Tall Tales Told by Ed Grant in Maine. Illustrated by Leonard Everett Fisher. New York: Dodd, Mead \& Company, 1961. Ages 10 up.

\section{Fenton, Carroll Lane}

Along Nature's Highway. With illustrations by the author. New York: The John Day Company, 1943. Ages 8-14.

Along the Hill. With illustrations by the author. New York: The John Day Company, 1935. Ages 10 up. 
Animals and Plants. Written and illustrated by Carroll Lane Fenton. New York: The John Day Company, 1962. Ages 8-12.

Animals that Help Us; The Story of Domestic Animals. By Carroll Lane Fenton and Herminie B. Kitchen. New York: The John Day Company, 1959. Ages 8-12.

Birds and Their World. By Carroll Lane Fenton and Dorothy Constance Pallas. New York: The John Day Company, 1954. Ages 6-10.

Birds We Live With. By Carroll Lane Fenton and Herminie B. Kitchen. New York: The John Day Company, 1963. Ages 9-12.

Desert Neighbors. By Edith Marion Patch and C. L. Fenton. Drawings by Carroll Lane Fenton. New York: The Macmillan Company, 1937.

Earth's Adventures. With more than 100 illustrations. New York: The John Day Company, 1942. Ages 12 up.

Forest Neighbors. By Edith Marion Patch and C. L. Fenton. Drawings by Carroll Lane Fenton, New York: The Macmillan Company, 1938.

The Fossil Book; A Record of Prehistoric Life. By Carroll Lane Fenton and Mildred Adams Fenton. Garden City, New York: Doubleday \& Company, Inc., 1958.

Fruits We Eat. By Carroll Lane Fenton and Herminie B. Kitchen. Illustrated by Carroll Lane Fenton. New York: The John Day Company, 1961. Ages 9-14.

Goldie is $a$ Fish. Illustrated by the author. New York: The John Day Company, 1961. Ages 4-8.

Holiday Shore. By Edith Marion Patch and C. L. Fenton. Drawings by Carroll Lane Fenton. New York: The Macmillan Company, 1935.

In Prehistoric Seas. By Carroll Lane Fenton and Mildred Adams Fenton. Garden City, New York: Doubleday \& Company, Inc., 1962. Ages 8-12.

Insects and Their World. By Carroll Lane Fenton and Dorothy Constance Pallas. Illustrated by Carroll Lane Fenton. New York: The John Day Company, 1956. Ages 6-10.

Inside You and $\mathrm{Me}$; $\mathrm{A}$ child's Introduction to the Human Body. By Eloise F. Turner and Carroll Lane Fenton. Illustrated by Lee Smith. New York: The John Day Company, 1961. Ages 4-8.

The Land We Live On. By Carroll Lane Fenton and Mildred Adams Fenton. Garden City, New York: Doubleday \& Company, Inc., 1944, 1966. Ages 6-10.

Life Long Ago; The Story of Fossils. Illustrated in full color and black and white. New York: The John Day Company, 1937. Ages 10-14.

The Moon for Young Explorers. Illustrated by the author. New York: The John Day Company, 1963. Ages 6-12.

Mountain Neighbors. By Edith Marion Patch and C. L. Fenton. Drawings by Carroll Lane Fenton. New York: The Macmillan Company, 1936.

Mountains. By Carroll Lane Fenton and Mildred Adams Fenton. Illustrated with photographs and drawings by the authors. Garden City, New York: Doubleday, Doran \& Co., Inc., 1942. Ages 12 up.

Oliver Pete is a Bird. By Carroll Lane Fenton and Dorothy Constance Pallas. New York: The John Day Company, 1959. Ages 4-8.

Our Amazing Earth. New York: Doubleday Company, Inc., 1938. (With drawings by Carroll Lane Fenton and photographs by Mildred A. Fenton and others). Ages 10 up. 
Our Changing Weather. By Carroll Lane Fenton and Mildred Adams Fenton. Garden City, New York: Doubleday \& Company, Inc., 1954. Ages 8-14.

Plants That Feed Us; The Story of Grains and Vegetables. By Carroll Lane Fenton and Herminie B. Kitchen. Illustrated by Carroll Lane Fenton. New York: The John Day Company, 1956. Ages 8-12.

Prairie Neighbors. By Edith Marion Patch and C. L. Fenton. Drawings by Carroll Lane Fenton. New York: The Macmillan Company, 1940.

Prehistoric World; Stories of Animal Life in Past Ages. With drawings by the author; color plates by James E. Allen. New York: The John Day Company, 1954. Ages 8-12.

Prehistoric Zoo. By Carroll Lane Fenton and Mildred Adams Fenton. Garden City, New York: Doubleday \& Company, Inc., 1959. Ages 7-12.

Reptiles and Their World. By Carroll Lane Fenton and Dorothy Constance Pallas. Illustrated by Carroll Lane Fenton. New York: The John Day Company, 1961. Ages 7-12.

Riches From the Earth. By Carroll Lane Fenton and Mildred Adams Fenton. Illustrated by the authors. New York: The John Day Company, 1953. Ages 9-14.

The Rock Book. By Carroll Lane Fenton and Mildred Adams Fenton. Illustrated with color plates, photographs and line drawings. New York: Doubleday, Doran \& Co., Inc., 1940. Ages 10 up.

Rocks and Their Stories. By Carroll Lane Fenton and Mildred Adams Fenton. Garden City, New York: Doubleday \& Company, Inc., 1951. Ages 12 up.

Tales Told by Fossils. Garden City, New York: Doubleday \& Co., 1966. Ages 12 up.

Trees and Their World. By Carroll Lane Fenton and Dorothy Constance Pallas. Illustrated by Carroll Lane Fenton. New York: The John Day Company, 1957. Ages 9-12.

Weejack and His Neighbor. Illustrations by the author. New York: The John Day Company, 1944. Ages 4-10.

Wild Folk at the Pond. Illustrations by the author. New York: The John Day Company, 1948. Ages 4-12.

Wild Folk at the Seashore. Illustrations by the author. New York: The John Day Company, 1959. Ages 6-14.

Wild Folk in the Desert. By Carroll Lane Fenton and Evelyn Carswell. Illustrated by Carroll Lane Fenton. New York: The John Day Company, 1958. Ages 6-14.

Wild Folk in the Mountains. Illustrations by the author. New York: The John Day Company, 1958. Ages 6-12.

Wild Folk in the Woods. Illustrations by the author. New York: The John Day Company, 1952. Ages 4-12.

Worlds in the Sky. By Carroll Lane Fenton and Mildred Adams Fenton. Illustrated by the authors. New York: The John Day Company, 1963. (New edition with extensive revisions.) Ages 8-14.

\section{Graham, Alberta Powell}

Christopher Columbus, Discoverer. Illustrated by Janice Holland. New York: Abingdon-Cokesbury Press, 1950. Ages 7-12. 
Clara Barton, Red Cross Pioneer. Illustrated by Clifford N. Geary. New York: Abingdon Press, 1956. Ages \&-12.

Great Bands of America. Frontispiece by Kurt Werth. New York: Thomas Nelson \& Sons, 1951. Ages 12 up.

Lafayette, Friend of America. Illustrated by Ralph Ray. New York: Abingdon-Cokesbury Press, 1952. Ages 7-12.

LaSalle, River Explorer. Illustrated by Avery Johnson. New York: Abingdon Press, 1954. Ages 8-12.

Strike Up the Band! Bandleaders of Today. New York: Thomas Nelson \& Sons, 1949. Ages 12 up.

Thirty-two Roads to the White House. Illustrated by George Avison. New York: Thomas Nelson \& Sons, 1944. Ages 10-14.

Washington: The Story of Our Capital. New York: Thomas Nelson \& Sons, 1953. Ages 10-16.

\section{Horn, Madeline Darrough}

Farm on the Hill. Illustrated by Grant Wood. New York: Charles Scribner's Sons, 1936. Ages 6-10.

Log Cabin Family. Illustrated by Francis McCray. New York: Charles Scribner's Sons, 1939. Ages 8-12.

The New Home. Illustrated by Harve Stein. New York: Charles Scribner's Sons, 1962. Ages 7-11.

\section{LeSueur, Meridel}

Chanticleer of Wilderness Road; A Story of Davy Crockett. Illustrations by Aldren A. Watson. New York: Alfred A. Knopf, 1951. Ages 10-14.

Little Brother of the Wilderness; 'The Story of Johnny Appleseed. Illustrated by Betty Alden. New York: Alfred A. Knopf, 1947, 1960. Ages 8-12.

Nancy Hanks of Wilderness Road; A Story of Abraham Lincoln's Mother. Illustrated by Betty Alden. New York: Alfred A. Knopf, 1949. Ages 8-12.

The River Road; A Story of Abraham Lincoln. Illustrations by Aldren A. Watson. New York: Alfred A. Knopf, 1954. Ages 10-14.

Sparrow Hawk. Illustrated by William Moyers. New York: Alfred A. Knopf, 1950. Ages 10-14.

\section{Meigs, Cornelia}

The Covered Bridge. Illustrated by Marguerite DeAngeli. New York: The Macmillan Company, 1936. Ages 10-14.

A Critical History of Children's Literature; A Survey of Children's Books in English from Earliest Times to the Present, Prepared in Four Parts Under the Editorship of Cornelia Meigs. By Cornelia Meigs, Anne Eaton, Elizabeth Nesbitt, and Ruth Hill Viguers. Decorations by Vera Bock, New York: The Macmillan Company, 1953.

The Dutch Colt. Illustrated by George and Doris Hauman. New York: The Macmillan Company, 1952. Ages 8-12.

Fair Wind to Virginia. Illustrated by John C. Wonsetler. New York: The Macmillan Company, 1955. Ages 10-14.

Hal und Peggy sitzen sich durch (translation of Fair Wind to Virginia). Mainz: Matthias-Grünewald-Verlag, 1955.

Helga and the White Peacock; a play in three acts for young people. With a frontispiece by Ruth Bingham, photographs by Margaret Browne, and 
notes on production from the Poughkeepsie Community Players. New York: The Macmillan Company, 1922. Ages 7-11.

The Kingdom of the Winding Road. Illustrations by Frances White. New York: The Macmillan Company, 1916. Ages 6-10.

Mother Makes Christmas. Pictures by Lois Lenski. New York: Grosset \& Dunlap (A Story Parade Picture Book), 1940. Ages 5-9.

Mounted Messenger. Decorations by John C. Wonsetler. New York: The Macmillan Company, 1943, 1945. Ages 10-16.

Franklins Postilion (translation of Mounted Messenger by John O. Ericsson). Stockholm: Oskar Eklunds Bokförlag, 1952.

Mystery at the Red House. Illustrated by Robert MacLean. New York: The Macmillan Company, 1961. Ages 9-14.

The New Moon; The story of Dick Martin's courage, his silver sixpence and his friends in the new world. New York: The Macmillan Company, 1924, 1946. Ages 10-16.

Rain on the Roof. Illustrated by Edith Ballinger Price. New York: The Macmillan Company, 1925, 1946. Ages 10-16.

The Scarlet Oak. Illustrations by Elizabeth Orton Jones. New York: The Macmillan Company, 1938. Ages 10-16.

The Steadfast Princess; A play for young people. New York: The Macmillan Company, 1916. Ages 8-12.

The Two Arrows. New York: The Macmillan Company, 1949. Ages 10-14.

Vanished Island. Illustrated by Dorothy Bayley. New York: The Macmillan Company, 1941, 1949. Ages 10-14.

Wild Geese Flying. Illustrated by Charles Geer. New York: The Macmillan Company, 1957. Ages 8-12.

Mysteriet med det vita huset (translation of Wild Geese Flying). Illustrations och omslag: Roy Böckbom. Stockholm: Eklund Tiden, 1959.

The Willow Whistle. Illustrated by E. Boyd Smith. New York: The Macmillan Company, 1931. Ages 8-12.

Wind in the Chimney. Illustrated by Louise Mansfield. New York: The Macmillan Company, 1934, 1947. Ages 8-12.

Lyckohjulet, Syskonen Morelands upple velser i det nya landet (translation of Wind in the Chimney). Stockholm: Ahlén \& Söners Förlag, 1935.

The Windy Hill. New York: The Macmillan Company, 1921, 1932. Ages $10-14$.

The Wonderful Locomotive: Illustrated by Berta and Elmer Hader. New York: The Macmillan Company, 1928, 1949.

Young Americans; How History Looked to Them While It was in the Making. A collection of stories by Cornelia Meigs. Boston: Ginn and Company, 1936. Ages 8-12.

\section{Poole, Lynn}

Balloons Fly High: 200 Years of Adventure and Science. By Lynn and Gray Poole. Illustrated by Richard Bergere. New York: McGraw-Hill Book Company, Inc., 1961. Ages 8-10.

Carbon-14 and Other Science Methods that Date the Past. By Lynn and Gray Poole. Illustrated by P. A. Hutchison. New York: McGraw-Hill Book Company, Inc., 1961. Ages Il up. 
Danger! Iceberg Ahead! By Lynn and Gray Poole. New York: Random House, 1961. Ages 6-9.

Deep in Caves and Caverns. By Lynn and Gray Poole. New York: Dodd, Mead \& Company, 1962. Ages 7-11.

Diving for Science. Pictures by Jeanne Beudick. New York: McGraw-Hill Book Company, Inc., 1955. Ages 12 up.

Fireflies in Nature and the Laboratory. By Lynn and Gray Poole. Illustrated by Christine Sapieha. New York: T. Y. Crowell, 1965. Ages 12 up.

Frontiers of Science. Illustrated by Sam Citron. New York: McGraw-Hill Book Company, Inc., 1958. Ages 12 up.

Insect-eating Plants. By Lynn and Gray Poole. Illustrated by Christine Sapieha. New York: T. Y. Crowell Co., 1963. Ages 7-10.

Science the Super Sleuth. Illustrated by Clifford N. Geary. New York: McGraw-Hill Book Company, Inc., 1954. Ages 12 up.

Scientists Who Changed the World. By Lynn and Gray Poole. New York: Dodd, Mead \& Company, 1960. ("Makers of Our Modern World" books). Ages 10 up.

Scientists Who Work With Cameras. By Lynn and Gray Poole. New York: Dodd, Mead \& Company, 1965. ("Makers of Our Modern World" books). Ages 12 up.

Volcanoes in Action; Science and Legend. By Lynn and Gray Poole. Line Drawings by Gustav Schrotter, New York: McGraw-Hill Book Company, Inc., 1962. Ages 9 up.

Weird and Wonderful Ants. By Lynn and Gray Poole. Illustrated by R. F. Peterson. New York: I. Oblensky, 1961. Ages 9 up.

Your Trip Into Space. Illustrated by Clifford Geary. New York: McGrawHill Book Company, Inc., 1953, 1958. Ages 12 up.

\section{Simmons, Ellie}

Cat. New York: David McKay Company, Inc., 1968. Ages Preschool-6.

Dog. New York: David McKay Company, Inc., 1967. Ages Preschool-6.

Mary Changes Her Clothes. New York: David McKay Company, Inc., 1960. Ages 4-8.

Mary, the Mouse Champion. New York: David McKay Company, Inc., 1963. Ages 5-8.

\section{Stong, Phil}

A Beast Called an Elephant. Pictures by Kurt Wiese. New York: Dodd, Mead \& Company, 1955. Ages 8-12.

Captain Kidd's Cow. Pictures by Kurt Wiese. New York: Dodd, Mead \& Company, 1941. Ages 10-14.

Kapten Kidds Ko. (Captain Kidd's Cow, translated by Esse Törnell). Stockholm: Ljus, (1947?) (Ljus ungdomsböcker, 25).

Censored, the Goat. Pictures by Kurt Wiese. New York: Dodd, Mead \& Company, 1945. Ages 7-12.

Cowhand Goes to Town. Pictures by Kurt Wiese. New York: Dodd, Mead \& Company, 1939.

Edgar: the 7:58. Illustrated by Lois Lenski. New York: Farrar and Rinehart, 1938. Ages 7-12. 
Farm Boy; A Hunt for Indian Treasure. Pictures by Kurt Wiese. Garden City, New York: Doubleday, Doran \& Company, 1934. Ages 8-12.

High Water. Pictures by Kurt Wiese. New York: Dodd, Mead \& Company, 1937. Ages 8-12.

The Hired Man's Elephant. Illustrated by Doris Lee. New York: Dodd, Mead \& Company, 1939. Ages 10-14.

Hirum the Hilibilly. Pictures by Kurt Wiese. New York: Dodd, Mead \& Company, 1951. Ages 10-14.

Honk: the Moose. Pictures by Kurt Wiese. New York: Dodd, Mead \& Company, 1936. Ages 8-12.

Honk der Elch. (Honk: the Moose, translated by Herbert Roch) Mit mehrfarbigen Zeichnungen von Kurt Wiese. Berlin: Gebrüder Weiss (1949?).

Mike; The Story of a Young Circus Acrobat. Pictures by Kurt Wiese. New York: Dodd, Mead \& Company, 1957. Ages 9-14.

Missouri Canary. Pictures by Kurt Wiese. New York: Dodd, Mead \& Company, 1943. Ages 8-12.

No-Stitch: the Hound. Pictures by Kurt Wiese. New York: Dodd, Mead \& Company, 1936. Ages 7-12.

Phil Stong's Big Book: Farm Boy; High Water; No-Stitch; the Hound. Pictures by Kurt Wiese. New York: Dodd, Mead \& Company, 1961. Ages 8-12.

Positive Petel Pictures by Kurt Wiese. New York: Dodd, Mead \& Company, 1947. Ages 7-14.

The Prince and the Porker. Pictures by Kurt Wiese. New York: Dodd, Mead \& Company, 1950. Ages 8-12.

Way Down Cellar. Pictures by Kurt Wiese. New York: Dodd, Mead \& Company, 1942. Ages 8-12.

Young Settler. Pictures by Kurt Wiese. New York: Dodd, Mead \& Company, 1938. Ages 8-12.

\section{Weir, Ruth Cromer}

Benjamin Franklin, Printer and Patriot. Illustrated by Rus Anderson. New York: Abingdon Press, 1955. Ages 8-12.

Christopher Columbus. Illustrated by Henry C. Pitz. Evanston, Illinois: Row, Peterson and Company, 1950 (Real People Series). Ages 9-14.

The Great Big Noise. Pictures by Esther Friend. Chicago: Wilcox \& Follett Co., 1948, reprinted 1963. Ages 4-7.

John Paul Jones, Father of the United States Navy. Illustrated by Frederick Seyfarth. Evanston, Illinois: Row, Peterson \& Company, 1950 (Real People Series). Ages 9-14.

John Paul Jones of the U.S. Navy. Illustrated by Edward Shenton. New York: Abingdon Press, 1958. Ages 8-12.

Leif Ericson, Explorer. Illustrated by Harve Stein. New York: AbingdonCokesbury Press, 1951. Ages 8-12.

Marco Polo. Illustrated by Rafaello Busoni. Evanston, Illinois: Row, Peterson and Company, 1951 (Real People Series). Ages 9-14.

Rags, An Orphan of the Storm. Pictures by Alice J. Montgomery. Chicago: Wilcox \& Follett Co., 1947. Ages 4-8. 
Science, Science, Everywhere! Illustrated by Gloria Stevens. New York: Abingdon Press, 1960. Ages 4-8.

Thomas Alva Edison, Inventor. Illustrated by Albert Orbaan. New York: Abingdon-Cokesbury Press, 1953. Ages 7-12.

The Wonderful Plane Ride. Illustrated by Fiore and Jacki Mastri. Chicago: Rand McNally \& Company, 1949. Ages 4-8.

The Wonderful Train Ride. Illustrated by Fiore and Jackie Mastri. Chicago: Rand McNally \& Company, 1947. Ages 4-8. 


\section{Farm On the Hill \\ By Madeline Darrough Hom}

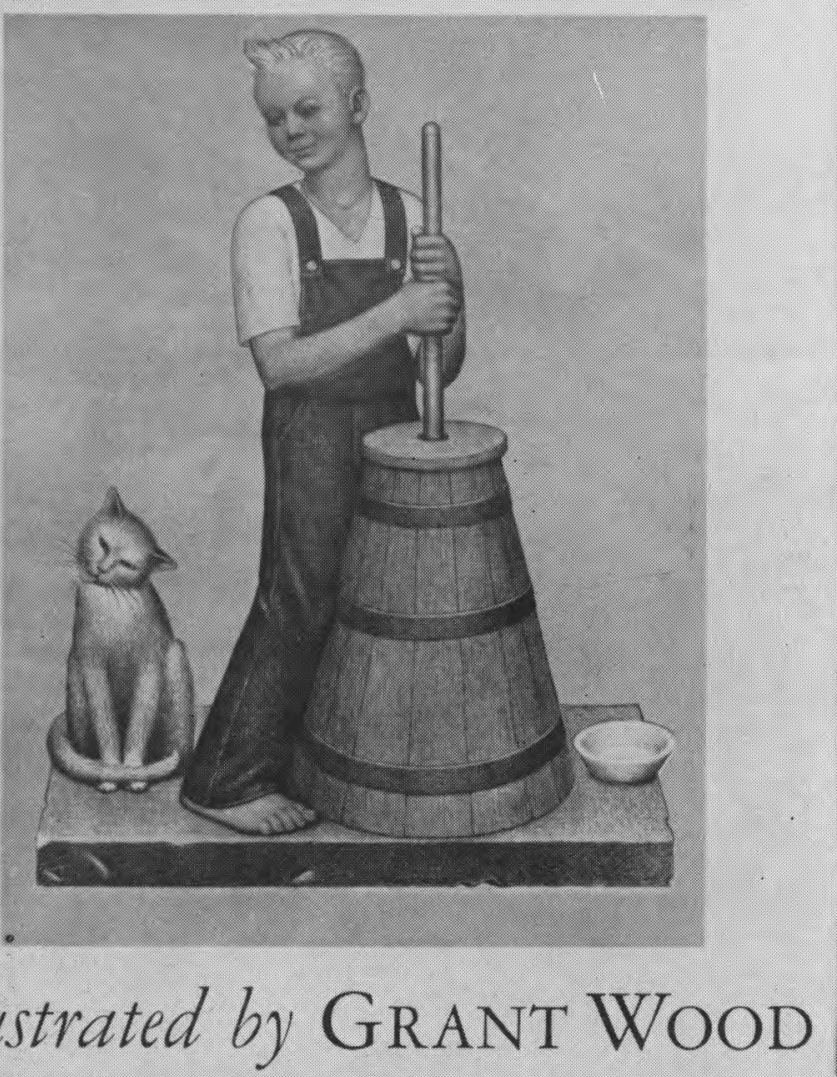

\section{Illustrated by GRANT WOOD}

Jacket design of a children's book from the Iowa Authors Collection, Madeline Darrough Horn's Farm on the Hill, illustrated by Grant Wood and published in 1936 by Charles Scribner's Sons. 